International Journal of Engineering \& Technology, $7(4.3)(2018) 419-425$
International Journal of Engineering \& Technology
SPC
Website: www.sciencepubco.com/index.php/IJET
Research paper

\title{
Formation of the Conceptual Basis of State Support for Development of Social Enterprises in Ukraine
}

\author{
Olena Dikan", Hanna Obruch*, Nataliia Panchenko ${ }^{1}$, Natalia Frolova ${ }^{1}$ \\ ${ }^{1}$ Ukrainian State University of Railway Transport \\ *Corresponding author E-mail: a_obruch@ukr.net
}

\begin{abstract}
The article deals with the phenomenon of social entrepreneurship. The importance of social enterprises in solving social problems and ensuring economic development of the state are outlined. The ranking of countries is based on the level of favorable conditions for the functioning of social enterprises, among which the most favorable conditions are characterized by the USA. The peculiarities of the state policy in the sphere of social enterprise development in South Korea are investigated, which, according to this rating, occupies the leading position among the countries in terms of state support of social business entities. The present state of development of subjects of social entrepreneurship in Ukraine is considered, which allowed to determine the main problems of their functioning. The conceptual basis of state support for the development of social entrepreneurship in Ukraine is formed, which is based on the definition of legal, financial, institutional and informational and consulting tools for the growth of social enterprises. Socio-economic effects of realization of social initiatives are revealed.
\end{abstract}

Keywords: Conceptual basis of state support for the development of social entrepreneurship; security tools; social entrepreneurship; social services; socio-economic effects.

\section{Introduction}

Today, social enterprise, which is positioned in world practice as an effective tool for implementing social policy at both the state and regional levels, is becoming more and more widespread in the world.

At present, Ukraine has accumulated a number of social problems that require urgent intervention. The most negative manifestations among them are: high unemployment, critical poverty of the population, strengthening of external labour migration, unacceptably critical level of state social protection of citizens, in particular social categories of the population, limited access to the labour market of people with disabilities, financial barriers to obtaining educational services, lack of proper correlation of quality and availability of medical services, low level of moral and ethical education in society, aggravation of environmental problems al.

Given the increasing social tensions in the country and the need to address these social problems, it is social entrepreneurship to be considered as an effective tool to overcome social imbalances and ensure the socio-economic development of the state.

Therefore, it is currently relevant to identify existing problems and to study the mechanism of state support for the development of social entrepreneurship in Ukraine in order to create tools for ensuring their growth.

\section{Analysis of Scientific Research and Publications on the Subject of Social Entrepreneurship}

The problem of the development of social entrepreneurship is a very relevant subject of the study, which is covered in scientific publications of domestic and foreign scientists, and is actively discussed at all-Ukrainian and international scientific events.

Specifically, researchers examined approaches to defining the essence the concepts social enterprise and social entrepreneurship, studied the basic criteria of a social enterprise type, the features of social enterprise entities, mechanisms and instruments to ensure their sustainable operation and so on.

Scientists emphasize that social entrepreneurship is a relatively new specific socioeconomic phenomenon that generates many reasons for discussion, since it does not fit stereotypes of perception of business as a commercial sphere that exists for profit Social entrepreneurship includes profitable and nonprofit directions, developing under «own laws». And the very phenomenon of social entrepreneurship involves understanding profit not as a goal, but as an indicator and resource business. Under such conditions, the economic opportunities of the entrepreneur are formed as a consequence of the usefulness of products or services to meet the needs of consumers [1].

Determining the essence of social enterprise and entrepreneurship is the focus of many scholars. Thus, K. Alter [2] defines a social enterprise as any business venture created for a social purpose mitigating/reducing a social problem or a market failure - and to generate social value while operating with the financial discipline, innovation and determination of a private sector business. The author also states that social enterprises differ in some key 
properties, providing double the value - economic and social, namely: use business tools and approaches to achieve social objectives; blend social and commercial capital and methods; create social and economic value; generate income from commercial activities to fund social programs; market-driven and mission-led; measure financial performance and social impact; meet financial goals in way that contributes to the public good; enjoy financial freedom from unrestricted income; incorporate enterprise strategically to accomplish mission.

A. Swinchuk [3] discloses the essence of social entrepreneurship as a systematic, including innovative, economic activity, which involves solving social problems. The author considers the social enterprise as a business organization, the priority objective of a transparent (public) activity of which is to solve social problems, and the supporting goal is to obtain a profit that is reinvested in its development.

S. Ponomarev [4] expresses the view that the essence of social entrepreneurship is that the income received is not the ultimate goal, but a means for solving significant social problems. That is, a significant part of the profit (up to 65\%) is reinvested, not distributed among shareholders and owners. Monetary funds serve as a resource for change, so often social entrepreneurs are called «changemakers» (those that make changes).

M. Naumova [5] considers the essence of social entrepreneurship as a socio-economic approach that focuses on important social problems, creatively combines and embodies social and business approaches to simultaneously create the social and economic value expressed in the enterprise's products. The author states that, unlike other areas of activity, social entrepreneurship can harmoniously combine high rates of economic growth of organizations with an increase in the quality of life of the population.

V. Dykan [6], in turn, emphasizes the importance of ensuring the social effect of the functioning of corporate integrated structures, which envisages ensuring the protection of human rights, the formation of stable labor relations, increasing the cost of health and safety, ensuring regional development and solving other problems the community.

V. Kompaniets [7] emphasizes the need to understand that the creation of a socially responsible business is impossible without raising the level of culture and morale of modern Ukrainian businessmen and managers, including acquisition of knowledge about the benefits that provide socially responsible activities, the ability to lead an honest and responsible business.

O. Polyakova [8], analyzing the concept of social entrepreneurship in the Ukrainian context, notes that the key to the successful development of social enterprises in Ukraine is the development of national strategies for the development of social entrepreneurship, which would allow coordinating the efforts of all interested parties. A clear and coordinated work of entrepreneurs, non-governmental organizations, donor structures and the state, as well as the financing of individual projects, is needed. These measures will solve the problem of social enterprise systematically.

N. Panchenko [9] identified the following as the most effective measures to extend the principles of social responsibility of business in Ukrainian society and stimulate commercial organizations to solve social problems: creation of favorable organizational and legal conditions for the activities of economic entities involved in solving social problems; granting of privileges on taxes, fees, rents and other payments to enterprises and organizations engaged in sponsorship and charitable activities; targeted financial support of non-state actors of social policy at the expense of budget funds; application of economic and other sanctions to those who harms the social interests of the territorial community; adaptation of the foreign experience of social entrepreneurship.

Considering the significant theoretical work of scientists and the crucial role of social enterprises in the implementation of government social and economic initiatives require more research perspective grounded operation of social enterprises in Ukraine and determining the strategic vectors of tools to ensure their sustainable development in the Ukrainian realities.

\section{Research of Problems and Perspectives for Development of Social Entrepreneurship}

\subsection{Definition of Modern Trends for Development of Social Entrepreneurship in the World}

At present, statistical studies on the development of social enterprises reflect the phenomenon of the birth and active dissemination of this type of business in the world: in Europe there are about 2 million social enterprises that account for $8 \%$ of the EU's GDP and provide employment for more than 14.5 million people [10]. For example, Britain has about 70 thousand social enterprises, which provides a total contribution to the economy of 24 billion pounds sterling and employment of almost 1 million workers [11]. Social cooperatives in Italy account for about $60 \%$ of social services in the country, and the aggregate turnover of these associations in 2015 was 7 billion euros [12]. In November 2017, according to official data, only 150 social enterprises operated in Ukraine. However, experts point out that their actual quantity is much higher [13].

The Thomson Reuters Foundation, together with Deutsche Bank, UnLtd and the Global Social Entrepreneurship Network in 2016, conducted the first global assessment of expert opinions on the degree of comfort of countries for the activities of social enterprises. The criteria for evaluation were state support for social enterprises (1st place - South Korea), the involvement of qualified personnel (USA), public understanding of social enterprise (Israel), the possibility of earning a living (Canada), accelerate the development of social entrepreneurship (Canada), access to investment (Canada). Based on the results of the evaluation, the corresponding rating is presented, according to which the TOP-10 countries according to the level of favorable development of social enterprises are: USA, Canada, United Kingdom, Singapore, Israel, Chile, South Korea, Hong Kong, Malaysia and France. Turkey was recognized as the country with the least favorable environment for conducting social business. Poland and Russia took the 18 and 31 positions respectively. Ukraine, in turn, has not even been included in the list of 44 analyzed countries [14].

Despite the important role of this type of enterprises in solving social problems, there is currently no clear definition of a social enterprise in international practice. However, there is an understanding of its basic characteristics: the main purpose of the social enterprise is the social impact, not the profit for owners or shareholders. Such an operator provides goods and services on the market under the business model, and profits are primarily used to achieve social goals. The European Commission has identified four main areas of activity of such enterprises: working integration (training and employment of people with disabilities, people who find themselves in difficult circumstances and unemployed); provision of individual social services in areas such as health care, social protection, vocational training, education, childcare services, services for the elderly or assistance to low income people); local development of depressed / vulnerable regions; other, which includes environmental protection, sports, art, culture and preservation of historical heritage, science, research and innovation, consumer protection, amateur sport [15].

According to the European Social Enterprise Law Association, in recent years there has been a boom in the development of a legal framework for social entrepreneurship in European countries. Governments can determine how will regulate the industry. For example, in Spain, Portugal, France, Greece, Croatia, a social enterprise can exist exclusively in the form of social cooperatives. Great Britain introduced a special kind - a company that works in the public interest. Other countries determine the conditions under which an operator operating in any legal form may obtain the status of a social enterprise. Such laws were adopted by the 
governments of Belgium, Denmark, Finland, Luxembourg and Slovenia. In these countries the status of a social enterprise can be obtained not only by cooperatives or private companies, but also by public, volunteer, charitable organizations and foundations [15] Of particular note is the study of the legal framework of social enterprise in South Korea, which ranked first rating the level of state support for social enterprises. Thus, the relevant law on the development of social entrepreneurship was adopted in 2007 , which provided a clear definition of social entrepreneurship, which included all types of commercial activities aimed at providing social services or creating jobs for vulnerable groups of the population. In addition, the law provides quite simple and measurable criteria for what business can be considered social. Assigning a charter to a social enterprise is based on certification, which subsequently opens up access to state support. The country has established and operates a multi-system of state support for social business, service organizations, helping to create businesses and start providing consulting services; centers of social entrepreneurship (business incubators) that provide leasing of the office, training and obtaining various advisory services, etc. At the national level there are the Korea Social Enterprise Promotion Agency and the Committee to support social entrepreneurship. These institutions are responsible for implementation of a set of measures to stimulate the development of social business - from information support and conferences to the formation of a professional community of social entrepreneurs, the development of economic co-operation between them and the provision of direct financial assistance. Ministry of Employment and Labor in South Korea, in its turn, develops and adopts five-year plans for the development of social entrepreneurship, which details the forms of support, benefits and financing conditions for social enterprises (for example, direct state support - grants, government procurement; assistance in the development of new markets; promotion of entrepreneurship; involvement of young people through the implementation of a national internship program at social enterprises, scholarships at universities for studying specialized courses, etc.) [16].

In Europe, the practice of "fair taxes" (freedom to pay part of taxes) has become widespread, which means the possibility of choosing which goals taxpayers' funds will be directed to. This practice applies to some taxes and fees in Switzerland, Austria, Poland and other countries, refers to the symbolic part: as a rule, up to $1 \%$ of the tax amount that can be earmarked for education, health care or social problems. For example, in Poland, taxpayers can count $1 \%$ of the tax on the account of one of the "public benefit organizations" on the basis of annual declarations. In the state established, the list of such organizations includes charitable organizations, social assistance funds, support funds for democracy, and so on. Part of the money goes to local organizations that solve a number of social problems, which improves the overall social level in the state and creates new jobs [17].

\subsection{Analysis of Problems Functioning Social Enterprises in Ukraine}

Analyzing the legislative and regulatory framework for the development of social enterprises in Ukraine, it has been established that at present, the definition of social entrepreneurship and the formation of a system of state regulation and support of its functioning have not been properly reflected in legislation. Today, the activities of social enterprises in the country are regulated by the Laws of Ukraine "On charity and charitable organizations", "On volunteering", "On public associations" etc. [18-20].

According to the published draft law "On social enterprises" social enterprise is defined entity created by legal and / or natural persons, priority is to achieve social outcomes, particularly in health, education, science, culture, environment, provision of social services and support for socially vulnerable groups of the population (the unemployed, the poor, the elderly, persons with disabilities and other persons established by the legislation). In addition, in this bill deals with legal conditions for the establishment, operation and elimination of social enterprise criteria for enterprise social status, system of state support for social enterprises, etc. [21]. However, at present, the draft law has the status of a matter that is instructed to prepare and finalize for consideration at the session [22]

Taking into account the lack of legislative and regulatory support for the development of social entrepreneurship in Ukraine, social enterprises are currently operating as ordinary entrepreneurs or on the basis of cooperation with charitable organizations and foundations. Therefore, there is practically no opportunity for such enterprises to receive benefits. According to the Tax Code of Ukraine on tax exempt only those companies in which the number of disabled is at least $50 \%$ of the average number of full-time employees, provided that the fund pay for such disability is at least $25 \%$ of the total labor costs in the reporting period [23]. In the context of the above, it is expedient to mention the attempt to secure such privilege as exemption from taxation of social enterprises' profit in the legislation, as stated in the draft Law «On Amendments to Article 154 of the Tax Code of Ukraine (Regarding State Support to Social Enterprises) ». However, this attempt was unsuccessful, the project was withdrawn [24].

An important step towards the formation of conditions for the growth of social business is the development of a National Strategy for Civil Society Development in Ukraine in 2016-2020 gg., the creation of which is conditioned by the need to create favorable conditions for the development of civil society, establishing effective interaction of the public with the state authorities, local self-government bodies on the basis of partnership, providing additional opportunities for the implementation and protection of human and civil rights and freedoms, meeting the public interests with the use of various forms of democracy participation, civic initiative and selforganization. It should also be noted that among the main tasks of the strategy are those that directly concern social enterprises: stimulating the development of social entrepreneurship, in particular, improving the mechanisms for financial support for such activities; introduction of the practice of purchasing social and other socially important services through social order and ensuring equal access of civil society organizations and budget institutions to providing such services at the expense of budgetary funds; providing civil society organizations that provide social services at the expense of budget funds, the right to use state and communal property on preferential terms; ensuring the right of non-profit organizations of civil society to carry out business activities in accordance with the law, if such activities are consistent with the purpose of the organization of civil society, promote its achievement and does not foresee the distribution of income received, or part thereof, among the founders, members of such organization [25]. This allows us to conclude that non-profit enterprises, in particular charitable foundations, are public organizations. Such organizations do not foresee the conduct of entrepreneurial activity, which involves the distribution of profits among the participants.

The experts, in turn, highlighted several key nuances of creating social enterprise. First, this is a way of registering an enterprise either an individual entrepreneur or a limited liability company. Of course, creating a private enterprise is less burdensome and costly. However, in this case, it becomes of paramount importance to clearly define in the charter of the enterprise the main purpose and the task of its creation, in particular the outline of the social problem to be addressed by the activity of the enterprise.

Another aspect of the formation of a social enterprise is the question of financing all spheres of its activity. Due to the lack of a legislative framework, Ukraine has limited opportunities to attract foreign investment for the development of social enterprises. In most cases there is the possibility of a loan at the bank on usual terms as an entrepreneur. But now there are banks that are ready to provide benefits to social enterprises. For example, the interest rate on a loan for such a business can be 
reduced by $2 \%$ per annum, and the commission for granting a loan - by $1,5 \%$.

Second, you can create a public organization or a charitable foundation. Currently, public organizations, which employ vulnerable people, make out income from their work as donations from organizations that receive goods or services. In this case, there is an opportunity to apply for a grant from enterprises engaged in charitable activities. In practice, the size of such a grant can reach 100 thousand UAH. Thirdly, when creating a social enterprise it is possible to register separately a charitable and commercial organization, and apply for loans and grants. As the enterprise evolves, it is possible to submit documents for a combined program of assistance: $50 \%$ - preferential loan and $50 \%$ - grant. At present, you can get up to 200 thousand UAH for such a program [26].

An analysis of trends in the development of social enterprises in Ukraine has revealed a number of problems in their functioning: the lack of a public understanding of the essence and main objectives of social entrepreneurship, which is connected, first of all, with the insufficient level of its popularization in society and the imperfection of legislation in the field of creation and functioning of social enterprises; encumbrance of enterprises, including social direction, bureaucratic procedures; spreading public distrust in charity activities; low level of state support for the development of social entrepreneurship; limited sources of financial support and the complexity of the search for investors to finance social projects; the lack of entrepreneurial education in the initiators of the creation of a social enterprise; low income of the population, which limits its financial capabilities regarding the participation in social activities, etc.

Significant negative influence among the outlined problems of the development of social entrepreneurship is the lack of start-up capital for the creation of a social enterprise and the complexity of the search for investors to finance social projects. The decision of the task at the state level is problematic, which is connected with the deficit of the state budget and the aggravation of the problem of repayment of state borrowings. Domestic social enterprises can only hope for grants and use of preferential lending instruments from international organizations.

Now Ukraine has a program of social investment WNISEF (American fund Western NIS Enterprise Fund), aimed at providing support to private enterprises and individual entrepreneurs to achieve social and environmental impact through the use of the mechanism available credit in cooperation with banks, providing training and consultancy services, coaching and mentoring. The program of social investment provides for the provision of low interest loans for sustainable social enterprises, their counseling and support in the implementation and implementation of business plans. The fund provides an initial contribution to obtain a loan, the amount of which can range from 10 thousand dollars up to 100 thousand dollars in UAH equivalent with an interest rate of 5-10\% for 36 months [27]. The program is implemented jointly with such banks as Oschadbank and Kredobank.

The German-Ukrainian Fund (GUF) has been widely disseminated to support the development of small and medium-sized enterprises (SME). In 2017 the Program for supporting the financing of investment projects of SMEs was approved, which provides for the allocation of 300 million UAH for 40 years. The partner banks will receive bonuses in proportion to the share of SME investment loans in the loan portfolio and the number of new jobs created. As part of the program signed loan agreements with ProCreditBank amounting to $110 \mathrm{mln}$. USD, Kredobank - $100 \mathrm{mln}$. USD, Ukrgasbank - $81 \mathrm{mln}$. USD. These agreements have expanded access to credit for SMEs interest rate of $15 \%$ annually in local currency. At the end of 2017 the German-Ukrainian Fund and the Kyiv City State Administration presented a joint program of compensation of interest rates for loans to SMEs in Kiev, results of which will reduce lending interest rate to $7.5 \%$. Also, a tripartite Agreement on Cooperation in Support of Financing and Development of SMEs of Kharkiv Oblast between the GUF, the
Kharkiv Regional State Administration and the Association of Private Employers of the Kharkiv Region was signed [28]. These measures can become effective mechanisms for supporting the development of entrepreneurship in Ukraine, including social enterprises.

According to the National Bank of Ukraine, in March 2018, weighted average interest rates on loans granted to non-financial corporations accounted for $16.9 \%$ in the national currency and $6.7 \%$ in foreign currency, for households $-30.0 \%$ and $8.0 \%$ in accordance. For example, Oschadbank offers several types of loans to finance small and medium-sized businesses: replenishment of working capital (the term of the loan is up to 3 years, the interest rate - from $17.5 \%$, the commission on issue - from $0.2 \%$ ); purchase of vehicles and equipment (loan term - up to 5 years, interest rate - from 17,0\%, commission on issue - from $0.2 \%$ ); overdraft (interest rate - from $17.0 \%$, commission on issue - from $0.5 \%$ ), etc. [29].

A wide range of credit lines for small and medium-sized businesses is offered by Kredobank: replenishment of working capital (term of the loan - up to 2 years for legal entities and up to 1 year for individual entrepreneurs, fixed interest rate - $19.25 \%$ ); purchase of vehicles and equipment (loan term - up to 5 years, fixed interest rate $-19.75 \%$ ); overdraft (term of the loan - up to 1 year, interest rate - from $16.75 \%$, commission on issue - from $0.5 \%$ ), etc. [30]. Also, as noted above, the bank participates in the program of lending to social enterprises. The main criteria for obtaining such a loan are the following: the company must be a registered legal entity, in accordance with the current legislation of Ukraine, or a sole trader and carry on business; the social purpose of the enterprise must be clearly defined in the official documents; also, the mechanism of distribution of profits should be clearly defined with the definition of the share of profit aimed at social purpose [31].

Also, an important issue is the formation of a state infrastructure supporting the development of social entrepreneurship. Currently, one of such institutions in Ukraine is the Ukrainian Social Investment Fund, a non-profit organization, which created primarily for the purpose of supporting the least socially protected population, as well as initiatives of territorial communities and public organizations. The fund provides for financing of social projects at the expense of international investments in the following areas: creation of innovative models of social services for vulnerable groups of the population; repair of social and communal infrastructure facilities in rural areas; development of the potential of territorial communities in solving local problems, activating their participation in the decision-making process [32]. The project "Promoting the Development of Social Infrastructure UFSI.V" is being implemented at the expense of the grant from Germany, which is aimed at the development of the East of Ukraine and is being implemented in the Dnipropetrovs'k, Kharkiv and Zaporizhzhia regions and some cities of Donetsk and Luhansk regions [33].

\section{Development of Conceptual Bases of State Support for Social Entrepreneurship in Ukraine}

Taking into account the urgent need for solving social problems and the underdeveloped mechanism of state support for social enterprises, it is worth emphasizing that at present the importance of forming a conceptual basis for state support for the development of social entrepreneurship in Ukraine, which is based on the definition of legal, financial, institutional and informational and consultative means for the growth of the social entrepreneurship sector through the formation and implementation of social entrepreneurship initiatives (Fig. 1). The Agency for State Regulatory and Support to the Development of Social Entrepreneurship should become the controlling and coordinating body of state power that will ensure the implementation of the conceptual bases for the growth of social enterprises. 
Thus, the legal field for the development of social entrepreneurship in Ukraine should be formed first of all through the use of such instruments:

- legislative support for the development of social entrepreneurship entities, which primarily involves the elaboration and adoption of a law on the foundations for the establishment and operation of social enterprises; legislative consolidation of preferential terms of taxation of social enterprises, which provides for amendments to the Tax Code of Ukraine;

development and implementation of regional programs for the development of social entrepreneurship, especially for regions with a high level of social tension, etc.

\begin{tabular}{|c|c|c|c|c|c|c|}
\hline \multicolumn{7}{|c|}{ Key social problems of Ukrainian society } \\
\hline high unemployment & \multicolumn{3}{|c|}{$\begin{array}{c}\text { critical poverty of the } \\
\text { population }\end{array}$} & \multicolumn{2}{|c|}{$\begin{array}{c}\text { strengthening of external } \\
\text { labour migration }\end{array}$} & $\begin{array}{l}\text { low earnings and welfare of } \\
\text { the population }\end{array}$ \\
\hline \multicolumn{2}{|c|}{$\begin{array}{l}\text { limited access to the labour } \\
\text { market of people with } \\
\text { disabilities }\end{array}$} & \multicolumn{3}{|c|}{$\begin{array}{c}\text { lack of proper correlation of } \\
\text { quality and availability of } \\
\text { medical services }\end{array}$} & \multicolumn{2}{|c|}{$\begin{array}{c}\text { unacceptably critical level of state social } \\
\text { protection of citizens, in particular social } \\
\text { categories of the population }\end{array}$} \\
\hline \multicolumn{3}{|c|}{$\begin{array}{l}\text { low level of moral and ethical } \\
\text { education in society }\end{array}$} & \multicolumn{3}{|c|}{$\begin{array}{c}\text { financial barriers to obtaining } \\
\text { educational services }\end{array}$} & $\begin{array}{c}\text { aggravation of environmental } \\
\text { problems }\end{array}$ \\
\hline
\end{tabular}

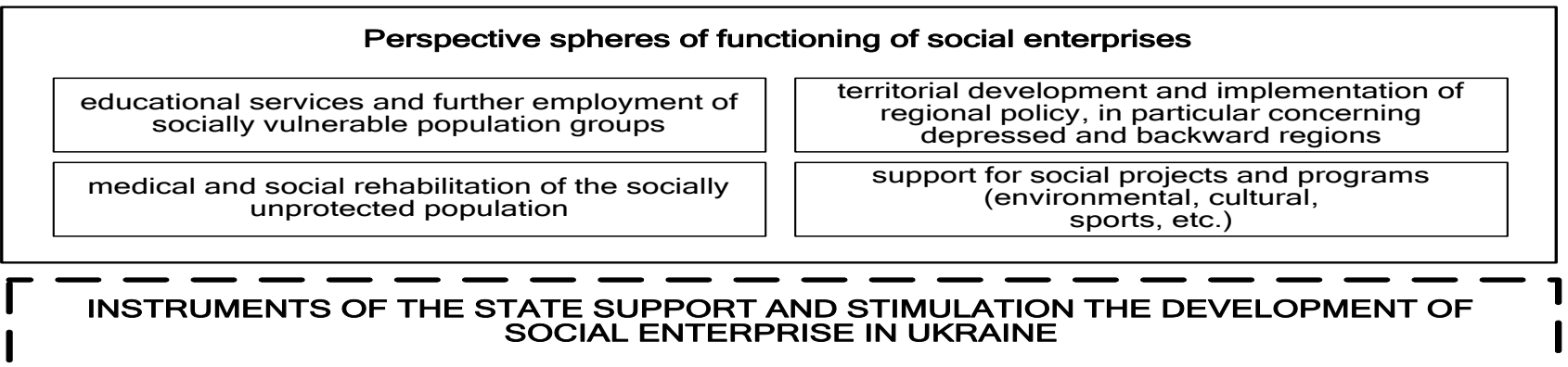

\begin{tabular}{|c|c|c|}
\hline \multicolumn{3}{|c|}{$\begin{array}{c}\text { Objective: To ensure the development of the social enterprise sector through the formation and implementation of } \\
\text { social business initiatives }\end{array}$} \\
\hline $\begin{array}{c}\text { Legal instruments } \\
\text { supporting the } \\
\text { development of } \\
\text { social } \\
\text { entrepreneurship } \\
\text { Tegrsanve sappor Tor } \\
\text { the development of } \\
\text { social entrepreneurship } \\
\text { entities; } \\
\text { - legal preferences in } \\
\text { the field of licensing of } \\
\text { social enterprises; } \\
\text { - levelling of } \\
\text { administrative barriers } \\
\text { for social } \\
\text { entrepreneurship; } \\
\text { - legislative } \\
\text { consolidation of } \\
\text { preferential terms of } \\
\text { taxation of social } \\
\text { enterprises; } \\
\text { - development and } \\
\text { implementation of } \\
\text { regional programs for } \\
\text { the development of } \\
\text { socialentrepreneurship. }\end{array}$ & 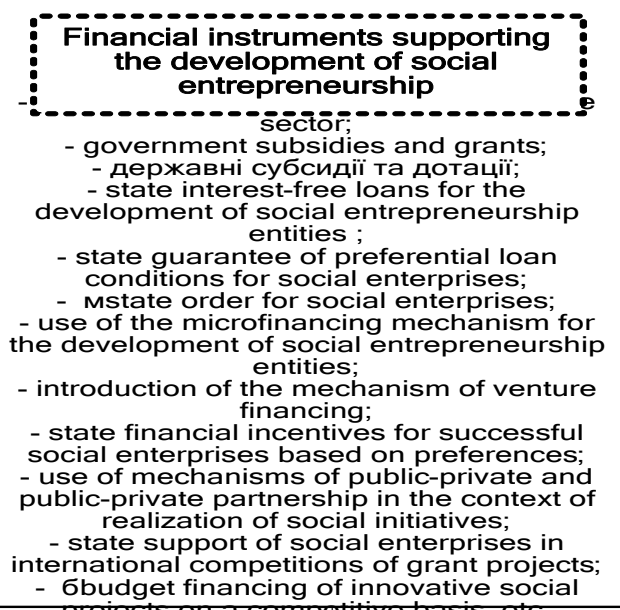 & $\begin{array}{c}\text { Institutional and informational and } \\
\text { consultative instruments } \\
\text { supporting the development of } \\
\text { social entrepreneurship } \\
\text { - Agency for State Regulation and Support } \\
\text { for the Development of Social } \\
\text { Entrepreneurship; } \\
\text { - regional departments for the development } \\
\text { of social enterprises; } \\
\text { - informational and consulting online } \\
\text { platform for the development of social } \\
\text { entrepreneurship; } \\
\text { - conferences, seminars and business } \\
\text { trainings on activation and dissemination of } \\
\text { social entrepreneurship initiatives; } \\
\text { - state order for the training of specialists in } \\
\text { the field of social entrepreneurship; } \\
\text { - providing cooperation and sharing of } \\
\text { experience between international and } \\
\text { national social enterprises; } \\
\text { - implementation of the state program of } \\
\text { mentoring of social entrepreneurs, etc. }\end{array}$ \\
\hline $\begin{array}{r}\text { - developmer } \\
\text { - developme } \\
- \text { in } \\
\text { - invol } \\
\text { pprovement of the }\end{array}$ & $\begin{array}{l}\text { - formation of the social enterpri } \\
\text { - activation of small business de } \\
\text { - the formation of a competitive market } \\
\text { ensuring the quality implementation of } \\
\text { on of new jobs, in particular for vulnerable } \\
\text { e level of social tension and strengthenin } \\
\text { ction of an associative type of relations be } \\
\text { - creation and implementation of soc } \\
\text { he culture of social business and the form } \\
\text { - activation of social activity of the } \\
\text { dimplementation of socially responsible } \\
\text { ement of the mechanism of protection of } \\
\text { nt of young people for the development } \\
\text { ational rating of the country by the level } \\
\text { social enterprise, etc. }\end{array}$ & $\begin{array}{l}\text { hent; } \\
\text { ial services; } \\
\text { cial services; } \\
\text { os of the population; } \\
\text { al relations in the country, } \\
\text { the state and society, } \\
\text { ovation; } \\
\text { pf a socially responsible society; } \\
\text { prises; } \\
\text { ss models by business entities; } \\
\text { rights and freedoms; } \\
\text { lentrepreneurial activity, } \\
\text { able environment for the develop }\end{array}$ \\
\hline
\end{tabular}

Fig. 1: The conceptual basis for state support of social entrepreneurship in Ukraine.

legal preferences in the field of licensing of social enterprises, which in particular requires the introduction of amendments to the Law of Ukraine "On Licensing Types of Economic Activities";

- levelling of administrative barriers for social entrepreneurship that requires changes to the relevant legislative acts;
For the financial support of the development of social entrepreneurship in Ukraine, it is necessary to ensure the use of the following state support instruments:

public investment in the social enterprise sector;

government subsidies and grants; 
- state interest-free loans for the development of social entrepreneurship entities through the allocation of subventions from the state budget to local budgets for the provision of state support to social enterprises, implementation by the state of intermediary and guarantee functions between social enterprises and commercial banks on the issue of interest-free loan;

- state guarantee of preferential loan conditions for social enterprises on the basis of conclusion of agreements on cooperation between the state and commercial banks in the field of preferential crediting of social entrepreneurs;

- state order for social enterprises, which provides for the priority access of social enterprises to the execution of state orders - use of the microfinancing mechanism for the development of social entrepreneurship entities, in particular such instruments as crowdfunding and kraudlending, which is possible on the basis of the introduction of state-sponsored microcrediting programs;

- introduction of the mechanism of venture financing;

- state financial incentives for successful social enterprises based on preferences;

- use of mechanisms of public-private and public-private partnership in the context of realization of social initiatives, which involves the active involvement of the subjects of national business;

- state support of social enterprises in international competitions of grant projects;

- budget financing of innovative social projects on a competitive basis, etc.

The institutional and informational and consultative support for the development of social entrepreneurship in Ukraine should be implemented through:

- the formation of the Agency for state regulation and support for the development of social entrepreneurship as a state institutional structure created to coordinate activities and provide a comprehensive stimulus for the growth of social enterprises;

- creation of regional departments for the development of social enterprises within the existing regional centres of entrepreneurship development;

- development of informational and consulting online platform for the development of social entrepreneurship;

- conducting of conferences, seminars and business trainings on activation and dissemination of social entrepreneurship initiatives with the involvement of leading scholars and practitioners in the field of social entrepreneurship;

- state order for the training of specialists in the field of social entrepreneurship on the basis of adjustment of curricula of higher education institutions of this specialization;

- providing cooperation and sharing of experience between international and national social enterprises on the basis of the implementation of relevant programs;

- implementation of the state program of mentoring of social entrepreneurs, etc.

\section{Conclusion}

It was determined that in conditions of aggravation of social tension in society and the critical need for solving social problems, social entrepreneurship acts as an effective tool for the implementation of social policy at the state and regional levels. The key problems of the functioning of social enterprises in Ukraine are investigated, among which the most important impact is the need to improve the legislation on the development of social entrepreneurship, the absence of preferential conditions for ensuring their functioning and limited access to sources of funding. As scientific novelty presented conceptual basis for state support of social entrepreneurship in Ukraine, which based on the formation of instruments of legal, financial, institutional and information and consultation support to ensure the growth of social enterprises. Specifically, it was determined the necessity of forming state institution in the field of functioning of social enterprises - the Agency for state regulation and support the development of social enterprises, the key functions of which will control, coordination and comprehensive support of social enterprises. Creation of this kind of organizational structure will allow achieving a number of socio-economic effects of realization social initiatives:

- formation of the social enterprise sector;

- activation of small business development;

- the formation of a competitive market for social services;

- ensuring the quality implementation of state social services

- creation of new jobs, in particular for vulnerable groups of the population;

- reducing the level of social tension and strengthening social relations in the country;

- construction of an associative type of relations between the state and society;

- creation and implementation of social innovation;

- development of the culture of social business and the formation of a socially responsible society;

- activation of social activity of the enterprises;

- development and implementation of socially responsible business models by business entities;

- improvement of the mechanism of protection of human rights and freedoms;

- involvement of young people for the development of social entrepreneurial activity;

- improvement of the international rating of the country by the level of favorable environment for the development of social enterprise, etc.

\section{Reference}

[1] Galushka S "The phenomenon of social entrepreneurship: the concept and prospects of development in Ukraine", Economics, No. 148 , (2013), available online: http://papers.univ.kiev.ua/1/ekonomika/articles/galushka-zphenomenon-of-social-entrepreneurship-a-concept-and-prospectsof-de_18580.pdf, last visit: 24.04.2018.

[2] Alter SK Social Enterprise Typology”, Virtue Ventures LLC, No. 27, (2007)," available online: https://www.globalcube.net/clients/philippson/content/medias/down load/SE_typology.pdf, last visit: 25.04.2018.

[3] Svynchuk AA (2016), Organizational mechanism of social enterprises development in Ukraine, $\mathrm{PhD}$ Thesis, State Higher Educational Institution "Kyiv National Economic University named after Vadym Hetman", Kyiv, 2016, 21.

[4] Ponomarev S (2016), Russian and American practices in support of social entrepreneurship, Perm, 2016, 60 pp.

[5] Naumova M (2014), The essence of social entrepreneurship and its role in the socio-economic development of society, Ukraine: aspects of labor, No. 4, 34-39.

[6] Dykan V.L. (2014), Processes of formation strategies activity of corporate integrated structures, Scientific Bulletin of Kherson State University. Series "Economic Sciences", No. 9, Part 3, 88-91.

[7] Kompaniets VV (2013), The essence of corporate social responsibility: the basic approaches of Western scientific thought, Bulletin of the Khmelnytsky National University. Economic sciences No. 4 (1), 250-255

[8] Polyakova OM (2016), The Concept of Social Entrepreneurship in the Ukrainian Context, The bulletin of transport and industry economics, No. 56, 176-182.

[9] Panchenko NG (2017), Research of models of social responsibility in the business environment and the possibilities of their application in Ukraine, The bulletin of transport and industry economics, No 60, 24-33

[10] Madrid Declaration "The Social Economy, a business model for the future of the European Union", available online: http://www.lavoro.gov.it/notizie/Documents/2017-05-23DICHIARAZIONE-MADRID-English-Version.pdf/, last visit: 25.04.2018

[11] The Future of Business: State of Social Enterprise Survey 2017 available online: https://www.socialenterprise.org.uk/the-future-ofbusiness-state-of-social-enterprise-survey-2017/, last visit: 23.04.2018.

[12] Social cooperatives between the past and the future, New business. Social entrepreneurship, (2017), available online: http://www.nbforum.ru/interesting/experts/socialnye-koperativy.html, last visit: 26.04.2018. 
[13] Catalog of social enterprises of Ukraine 2016-2017 years, NGO "Youth Center on Problem of Transformation in Social Sector" SOCIUM-XXI" (2017), Kyiv, 2017, 302 p.

[14] The best countries to be a social entrepreneur 2016, available online: http://poll2016.trust.org/, last visit: 23.04.2018.

[15] Gulevskaya-Chernysh A. Social entrepreneurship: European takeoff vs. Ukrainian realism (March 17, 2018), Mirror of the week, No. 10 (356), 15.

[16] Social Entrepreneurship in South Korea: Five Years, Festivals and Grants (2018), New Business. Social entrepreneurship, available online: http://www.nb-forum.ru/business/foreign-experience/korea18.html, last visit: 26.04 .2018 .

[17] Tax freedoms: where will the taxes of Ukrainians (2016), Forbes Ukraine, available online: http://forbes.net.ua/nation/1418597nalogovye-svobody-kuda-pojdut-nalogi-ukraincev, last visit: 20.04.2018.

[18] On charitable activities and charitable organizations (2012), Law of Ukraine, Verkhovna Rada of Ukraine, available online: http://zakon5.rada.gov.ua/laws/show/5073-17, last visit: 21.04.2018.

[19] About volunteer activity (2011), Law of Ukraine, Verkhovna Rada of Ukraine, available online: http://zakon2.rada.gov.ua/laws/show/3236-17, last visit: 21.04.2018.

[20] On Public Associations (2012), Law of Ukraine, Verkhovna Rada of Ukraine, available online: http://zakon5.rada.gov.ua/laws/show/4572-17, last visit: 22.04.2018.

[21] Draft Law on Social Enterprises (2011), Verkhovna Rada of Ukraine, available online: http://w1.c1.rada.gov.ua/pls/zweb2/webproc4_1 ?id=\&pf3511=5490 3, last visit: 15.04.2018.

[22] On the agenda of the eighth session of the Verkhovna Rada of Ukraine of the eighth convocation (2018), Resolution of the Verkhovna Rada of Ukraine, available online: http://zakon3.rada.gov.ua/laws/show/2351-viii, last visit: 20.05.2018.

[23] Tax Code of Ukraine, Verkhovna Rada of Ukraine, available online: http://zakon3.rada.gov.ua/laws/show/2755-17/page?text=142, last visit: 15.04.2018.

[24] Draft Law "On Amendments to Article 154 of the Tax Code of Ukraine (Regarding State Support to Social Enterprises)" (2012), available online: http://w1.c1.rada.gov.ua/pls/zweb2/webproc4_1?pf3511=43735, last visit: 16.04.2018.

[25] On promoting the development of civil society in Ukraine (2016), Decree of the President of Ukraine, available online: https://www.kmu.gov.ua/ua/npas/249972001, last visit: 16.04.2018.

[26] Social business: give grants and concessional loans, but "in a plus" you will not go right away (2012), Business news. Today, available online: https://www.segodnya.ua/economics/business/cotsialnyjbiznec-dajut-hranty-i-lhotnye-kredity-no-v-pljuc-vyjdete-necrazu.html, last visit: 20.04.2018.

[27] Social Investment Program (2017), Western NIS Enterprise Fund, available online: http://wnisef.org/uk/impact-investing/, last visit: 20.04.2018.

[28] Results of implementation of the project "Support for Small and Medium Enterprises" in 2017 (2018), German-Ukrainian Fund, available online: http://guf.activemedia.ua/uk/news/resultati, last visit: 22.04 .2018 .

[29] Business Financing, Oschadbank, available online https://www.oschadbank.ua/ua/business/finansuvannya-biznesu/, last visit: 28.04.2018.

[30] Loans for small and medium businesses, KredoBank, available online:

https://www.kredobank.com.ua/for_small_business/credit_service.h tml\#.WwFQ1 tSLTDc, last visit: 28.04.2018.

[31] Lending to social enterprises in cooperation with WNISEF, KredoBank, available online: https://www.kredobank.com.ua/for_small_business/credit_service/ microcredit/10832.html\#.WtduUy5ubZ4, last visit: 28.04.2018.

[32] Directions of activity, Ukrainian Social Investment Fund, available online: http://www.usif.org.ua/uk/pronas/2011-11-30-12-46-06.html, last visit: 28.04 .2018 .

[33] Projects in 2018, Ukrainian Fund for Social Investments, available online: http://www.usif.org.ua/uk/proekti/2011-12-02-10-43-39/64potochni.html, last visit: 28.04.2018. 